\title{
Filter-net structure and pumping activity in the polychaete Nereis diversicolor: effects of temperature and pump-modelling
}

\author{
H. U. Riisgård ${ }^{1}$, A. Vedel ${ }^{1}$, H. Boye ${ }^{2}$, P. S. Larsen ${ }^{3}$ \\ ${ }^{1}$ Institute of Biology, Odense University, Campusvej 55, DK-5230 Odense M, Denmark \\ ${ }^{2}$ Institute of Anatomy, Odense University, Campusvej 55, DK-5230 Odense 11, Denmark \\ ${ }^{3}$ Department of Fluid Mechanics, Technical University of Denmark, DK-2800 Lyngby, Denmark
}

\begin{abstract}
Electron micrographs of the filter-net structure in the facultatively suspension-feeding polychaete Nereis diversicolor O. F. Müller showed that the net is composed of an irregular mesh-work made up of long, relatively thick filaments (up to $300 \mathrm{~nm}$ ) interconnected with a variety of shorter and thinner filaments. The thinner filaments range in diameter from 5 to $>25 \mathrm{~nm}$. The average size of the meshes, measured directly on the micrographs, lies between 0.5 and $1.0 \mu \mathrm{m}$, but due to shrinkage the values represent only about $75 \%$ of the actual dimension of the intact net. The effects of temperature on water processing were measured as clearance of suspended algal cells or measured directly. Pumping activity (undulating body movements of worms kept in glass tubes) was monitored using an infrared phototransducer technique. In the temperature interval from 5 to about $15^{\circ} \mathrm{C}$ there was a linear increase in clearance, and a doubling of the temperature was followed by a doubling in clearance. Direct measurements of pumping rate showed that high stroke frequency was correlated with high pumping rate. A doubling of temperature from 13 to $23-29^{\circ} \mathrm{C}$ led to a doubling of the stroke frequency and a halving of the net cycle length. At low temperatures a tendency towards an extended pause between pumping periods was noticed. The $N$. diversicolor pump was modelled as a positive displacement leaking unit, and earlier data on back pressure characteristics were examined in light of the proposed model. The pump model prediction of temperature dependence showed reasonably good agreement with experimental data. The consequences of leaving out the effect of viscosity or stroke frequency in the pump model were evaluated. Clearly, the temperature effect as related to viscosity is negligibly small in the $N$. diversicolor muscular positive displacement pump (unlike for viscous ciliary pumps).
\end{abstract}

\section{INTRODUCTION}

The facultatively suspension-feeding polychaete Nereis diversicolor has recently been suggested to be an undervalued, key organism in the control of phytoplankton production in shallow brackish-water areas, its population filtration rates being on the order of $10 \mathrm{~m}^{3} \mathrm{~m}^{-2} \mathrm{~d}^{-1}$ (Riisgård 1991). $N$. diversicolor lives in U-shaped tubes in soft sediment. In the presence of suspended algal cells, the worm spins a net-bag in the tube. By vigorously undulating body movements water is driven through the trapping-net. The net with the retained food particles is eaten after pumping periods of 5 to $10 \mathrm{~min}$. A new spinning and pumping cycle follows immediately there after (Harley 1950, Goerke 1966, Riisgård 1991). This presumably evolutionary late adaptation to a facultative life as a filter-feeder is not only interesting in an ecological context, but also in comparison with obligately suspension-feeding polychaetes, such as Chaetopterus variopedatus (Riisgård 1989) and Sabella penicillus (Riisgård \& Ivarsson 1990).

The aim of the present work was to undertake a more detailed study, including modelling, of the filter-pump system of Nereis diversicolor. The results serve both to aid our understanding of the filtration biology of $N$. 
diversicolor, and to further elucidate temperature effects on biological pumps, as initially reported by Jørgensen et al. (1990).

\section{MATERIALS AND METHODS}

Ragworms Nereis diversicolor O. F. Müller were collected in October 1990 from mud flats $(<0.5 \mathrm{~m}$ water

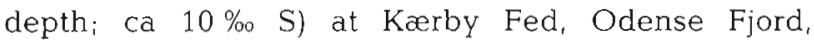
Denmark. In the laboratory the worms were transferred to glass tubes $(16 \mathrm{~cm}$ length; $4.0 \mathrm{~mm}$ internal diameter) and kept in aquaria $\left(14\right.$ to $16{ }^{\circ} \mathrm{C} ; 18$ to $20 \% \mathrm{~S}$ ) until preparation of net-samples and experiments could be performed.

Preparation of net-samples for electron microscopy (EM). Hydrophilic carbon films (about $10 \mathrm{~nm}$ thick) were prepared on mica in a Balzers BAF 301 with turbopump used as a vacuum evaporator. The carbon film was picked up on copper grids and used for adsorbing filter-nets without further treatment. When a worm had completed a net, it was forced to abandon it by injection of a solution of $2.5 \%$ glutaraldehyde. $1 \%$ formaldehyde, and $0.05 \mathrm{M}$ sodiumcacodylate in $60 \%$ seawater (filtered) into the inhalant end of the glass tube (Flood \& Fiala-Médioni 1982). The glass tube had been scored with a glass-cutter, so that one could easily break off the part into which the worm had retracted. The EM grid was placed inside the net and then withdrawn, with the net adhering to it. After a cautious blotting, the grid was air-dried. The grids were then examined in an electron microscope (Jeol 100CX) without further treatment. Staining with uranylacetate in aqueous solution did not notably enhance the contrast of the filaments, and the detrimental effects of rewetting the grids were therefore avoided.

Water pumping activity. Experimental procedures for measurement of water processing, by means of either the 'clearance method' (volume of water cleared of algal cells per unit time) or the 'direct technique', were the same as those adopted by Riisgard (1991). Pumping activity (undulating body movements of worms kept in glass tubes) was monitored using the 'infrared phototransducer technique' of Riisgård (1991).

The effects of temperature on clearance, pumping rate and stroke frequency (undulating body movements) were determined 1 to $12 \mathrm{~h}$ after a temperature change of 3 to $6{ }^{\circ} \mathrm{C}$ controlled by a thermostated water bath in which the aquarium with the worm(s) was placed.

When no literature references are given for fluid mechanical formulas or concepts these matters may be found in general textbooks (e.g Leyton 1975, Vogel 1981). General principles and characteristics of pumps are explained in many standard engineering handbooks, e.g. Marks (1941).

\section{RESULTS AND DISCUSSION}

\section{Food-trapping net}

Although the chemical composition of the foodtrapping net of Nereis diversicolor has not yet been studied, the filaments of the net probably consist of highly polymerised macromolecules resembling components of mucus. Such structures are thoroughly hydrated, and drying them, as done in the present work, would most likely cause them to shrink lengthwise and round structures to appear flat. Since the filaments appeared to be well-attached to the carbon-film on the EM grid, one would have expected any shrinkage to cause creases in the carbon film and ruptures in both filaments and film in places where the film was firmly fixed. Neither phenomenon was observed, and the few ruptures of the net that could be seen appeared to have taken place during the attempts to pick up the net on the EM grid, since the carbon film underneath was intact. Lacking indications of noticeable shrinkage, the dimensions reported below are considered representative of the intact net. Net length was reduced by ca $25 \%$ relative to the working size, with minimal width reduction. The $25 \%$ reduction in net length was determined by measuring the net length before and after injection of the glutaraldehyde/formaldehyde solution into the inhalant end of the tube containing the worm.

\section{Filament dimensions (Fig. 1)}

Keeping in mind that the filaments were probably flattened to some degree, measurements showed that the long, relatively thick filaments of the net had diameters up to $300 \mathrm{~nm}$. Some of these thick filaments appeared to consist of several strands fused together $A$ variety of shorter and thinner filaments interconnected with the long thicker filaments to form an irregular mesh-work. The thinner filaments varied in diameter from $5 \mathrm{~nm}$ to more than $25 \mathrm{~nm}$, and often they seemed to fuse with the thicker filaments. The thinnest filaments were often observed forming the longest side of a triangle, spanning the corner where thinner filaments joined with thicker ones. Even at a magnification of more than $100000 \times$ no obvious internal structures could be seen in the filaments.

\section{Mesh dimensions (Fig. 1)}

The largest dimension of any of the meshes, measured directly on the micrographs, varied from $<0.1 \mu \mathrm{m}$ in the triangular structures to $1.5 \mu \mathrm{m}$ for the biggest. meshes. Very few meshes were near-circular or near- 
Fig. 1. Nereis diversicolor. Electron micrographs of net produced by suspension-feeding worm. (A) Survey at low magnification demonstrating the variation in mesh size. (B) Detail at high magnification showing the relationship between thin and thick filaments

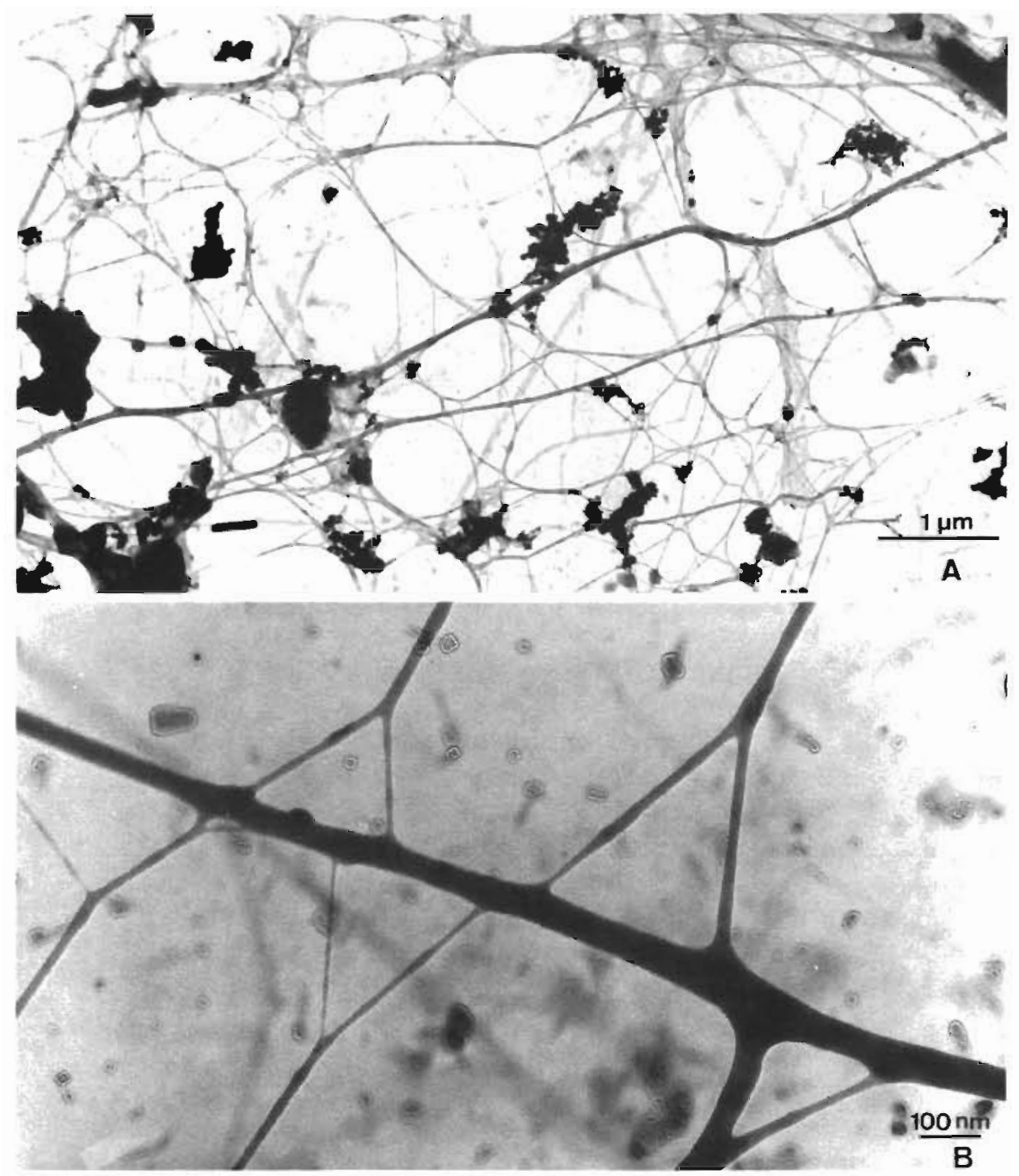

quadratic, so the average size of a hole lay between 0.5 and $1.0 \mu \mathrm{m}$. However, it should be remembered that these figures represent only about $75 \%$ of the actual dimensions of the intact net. Small particles (of $<0.1 \mu \mathrm{m}$ diameter) were occasionally picked up by the net, apparently by the small holes. If the filaments are just slightly flexible and elastic, the triangular structures may be able to catch very small particles that get wedged into the triangles.

\section{Effects of temperature}

Temperature effects on pumping activity were measured by means of various methods: clearance (Fig. 2); direct determination of pumping rate and stroke frequency (Fig. 3); and the infrared phototransducer technique (Figs. 4 \& 5).

Clearance as a function of acute change in temperature (2 to $6{ }^{\circ} \mathrm{C}$ within 15 to $30 \mathrm{~min}$ ) was measured in 3 worms acclimatized to $6^{\circ} \mathrm{C}$ during several weeks (Fig. 2). In the temperature interval from 5 to ca $15^{\circ} \mathrm{C}$ there was a linear increase in clearance, as indicated by the regression lines. In Worms \#8 and \#9 a doubling of temperature was followed by a doubling in clearance. At higher temperatures up to about $25^{\circ} \mathrm{C}$ clearance decreased. In the temperature range from 5 to $25^{\circ} \mathrm{C}$ the stroke frequency (i.e. undulating body movements) was seen to increase (from 25 strokes to 100 strokes $\min ^{-1}$ in \# 8, Fig. 3). Direct measurements of the pumping rate in \#9 at 19 to $22^{\circ} \mathrm{C}$ (Fig. 2) and in \# 10 at temperatures up to $26^{\circ} \mathrm{C}$ (Fig. 3 ) showed that high stroke frequency was correlated with high pumping rate, and thus, the low clearance might have been due to a leaky food-trapping net caused by high flow rates, or the mucous secretion may have been disturbed by the acute temperature increase. This interpretation is supported by the measurements of retention efficiency (Fig. 6). Particles down to at least 2 to $3 \mu \mathrm{m}$ were efficiently cleared from the water at 


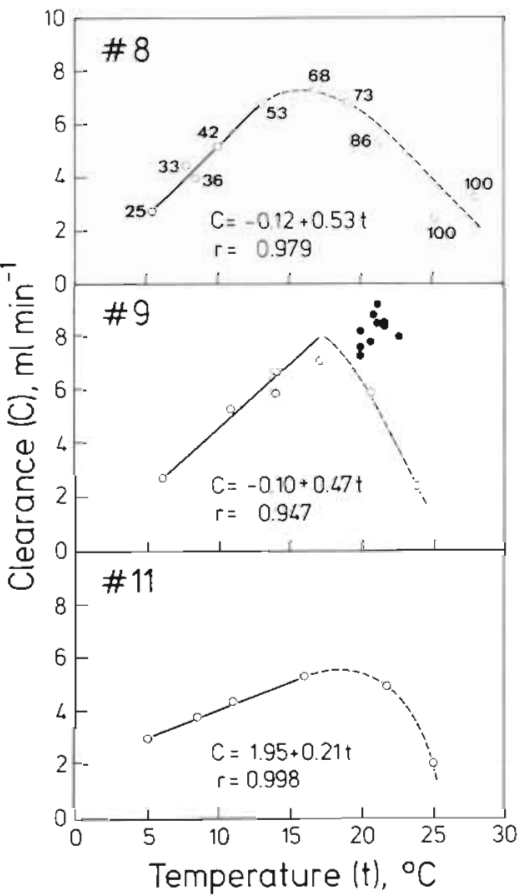

Fig. 2. Nereis diversicolor. Algal clearance as a function of temperature in experiments with 3 worms. Regression lines and their equations have been shown for temperature intervals where linear relationships are suggested (Worm \#8: 5.5 to $13^{\circ} \mathrm{C}$; \#11: 5 to $16^{\circ} \mathrm{C}$; \#9: 6 to $17^{\circ} \mathrm{C}$ ). Frequency of waterpumping, undulatory body movements (strokes $\mathrm{min}^{-1}$ ) counted by eye and using a stop-watch are indicated at a number of sampling times. Dashed lines, fitted by eye, show the pattern of decrease in clearance rate at higher temperatures. Pumping rate in the temperature range 20 to $22^{\circ} \mathrm{C}$ was measured in Worm \#9 using the direct technique immediately after the clearance experiment (closed symbols). Body dry weights: $\# 8=40 \mathrm{mg} ; \# 9=41 \mathrm{mg}_{i} \# 11=47 \mathrm{mg}$

temperatures of $17^{\circ} \mathrm{C}$ and less, but at higher temperatures clearance was reduced. At $19^{\circ} \mathrm{C}$ the net became ineffective in retaining particles smaller than ca $9 \mu \mathrm{m}$, and almost no particles up to this size were retained at $24^{\circ} \mathrm{C}$. The low retention efficiency of parti- cles smaller than ca $7 \mu \mathrm{m}$, previously found by Riisgård (1991), may be explained by a temperature effect similar to that demonstrated in the present work.

Fig. 6 indicates that the mesh dimensions in the intact net may be somewhat larger than shown by the micrographs (Fig. 1). More clearance measurements of small particles $(0.5$ to $3 \mu \mathrm{m}$ ) are, however, needed in order to identify more precisely the effective mesh size of the net.

Temperature also influenced the duration of net cycling, i.e. the time spent on net spinning, water pumping and net eating. An approximate doubling of the temperature from $13^{\circ} \mathrm{C}$ to $23-28{ }^{\circ} \mathrm{C}$ lead to a doubling of the stroke frequency and a halving of the net cycle length (Fig. 3). At low temperatures a tendency towards an extended pause between pumping periods was noticed.

Extended pauses between pumping periods were also seen at low algal concentrations (i.e. 2500 cells $\mathrm{mi}^{-1}$; see Fig. 5A). During a pause the worm often turned around or went to the tube entrances to examine the outside surroundings. When no algae were present in the water no net was spun, and pumping activity was low and sporadic (only to ventilate the tube). Addition of algae stimulated the worm to spin a net and to pump at a constant high rate usually within $10 \mathrm{~min}$. Algal concentration did not influence pumping period, stroke frequency, spinning time, net eating time or net length in the range between 0.25 and $5 \times$ $10^{4}$ cells $\mathrm{ml}^{-1}$ (Table 1 ).

\section{Pump model}

Any attempt to interpret the effect of temperature change on worm pumping rate requires a plausible model of the pumping system under isothermal conditions. In Nereis diversicolor the pumping action is a result of the wavy motion of the body in the confining

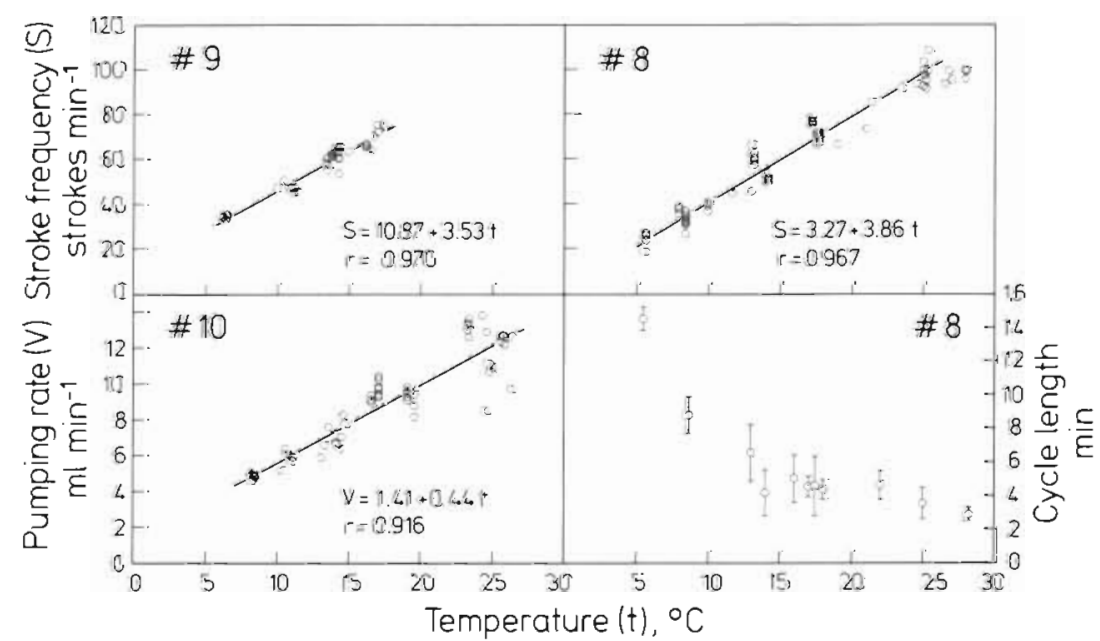

Fig. 3. Nereis diversicolor. Stroke frequency, pumping rate and length of net cycle (spinning-pumping-eating) as a function of temperature. Regression lines (Worm \#9: 6 to $17.4^{\circ} \mathrm{C}$; \#10: 8 to $26.2^{\circ} \mathrm{C}$. \#8: 5.5 to $25^{\circ} \mathrm{C}$ ) and means $\pm \mathrm{SD}$ (\#8) are shown. Body dry weights: $\# 8=40$ $\mathrm{mg} ; \# 9=41 \mathrm{mg} ; \# 10=35 \mathrm{mg}$ 


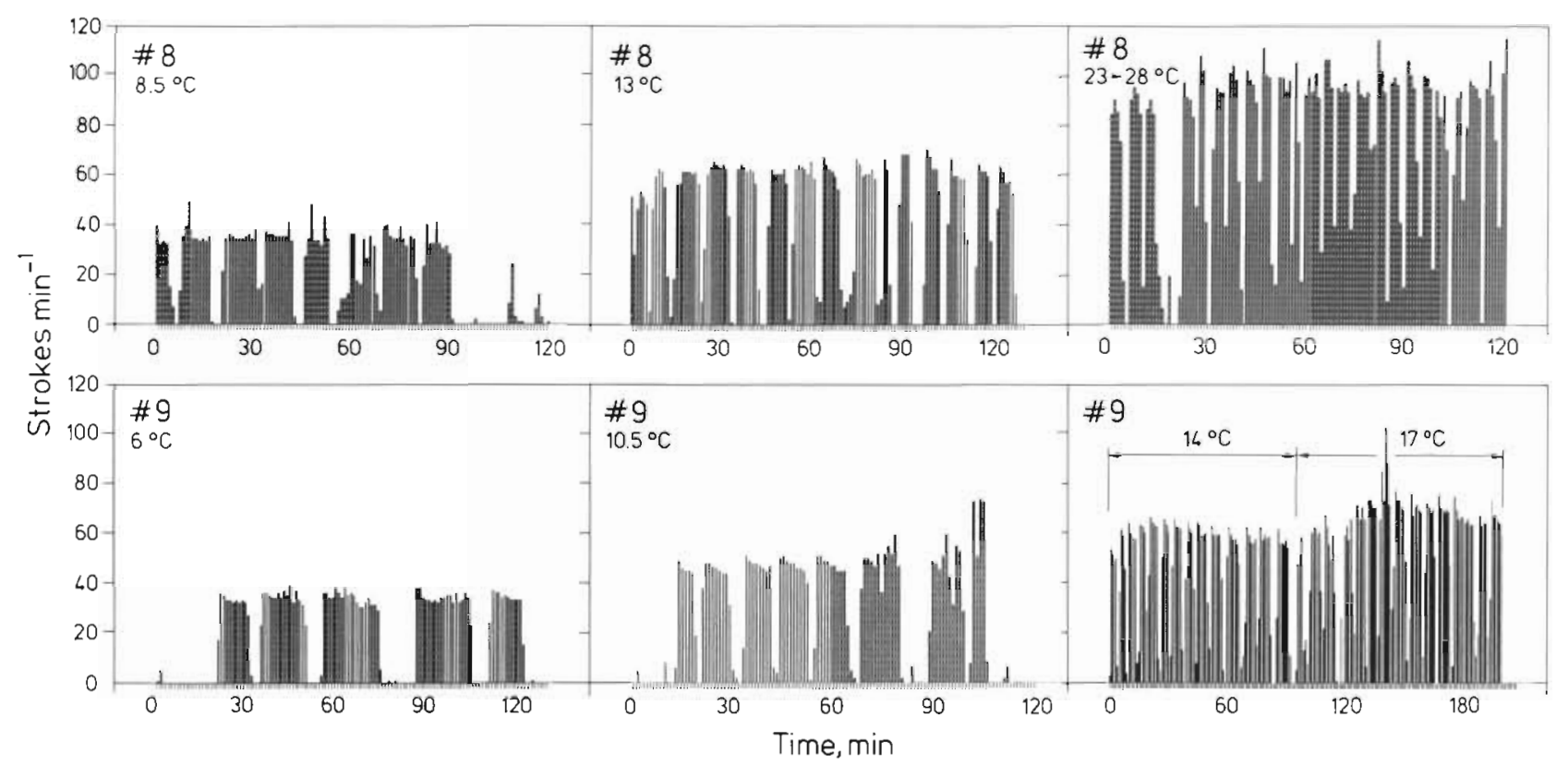

Fig. 4. Nereis diversicolor. Pumping activity (undulating body movements) in Worms \#8 and \#9 recorded at different temperatures using a phototransducer fastened to the glass tube holding the worm

Fig. 5. Nereis diversicolor. Pumping activity of Worm \#2 at different algal (Rhodomonas sp.) concentrations. (A) $2.5 \times 10^{3}$ cells $\mathrm{ml}^{-1}$; (B) $5 \times 10^{3}$; (C) $10^{4}$; (D) $1.5 \times 10^{4}$; (E) $2.6 \times 10^{4}$
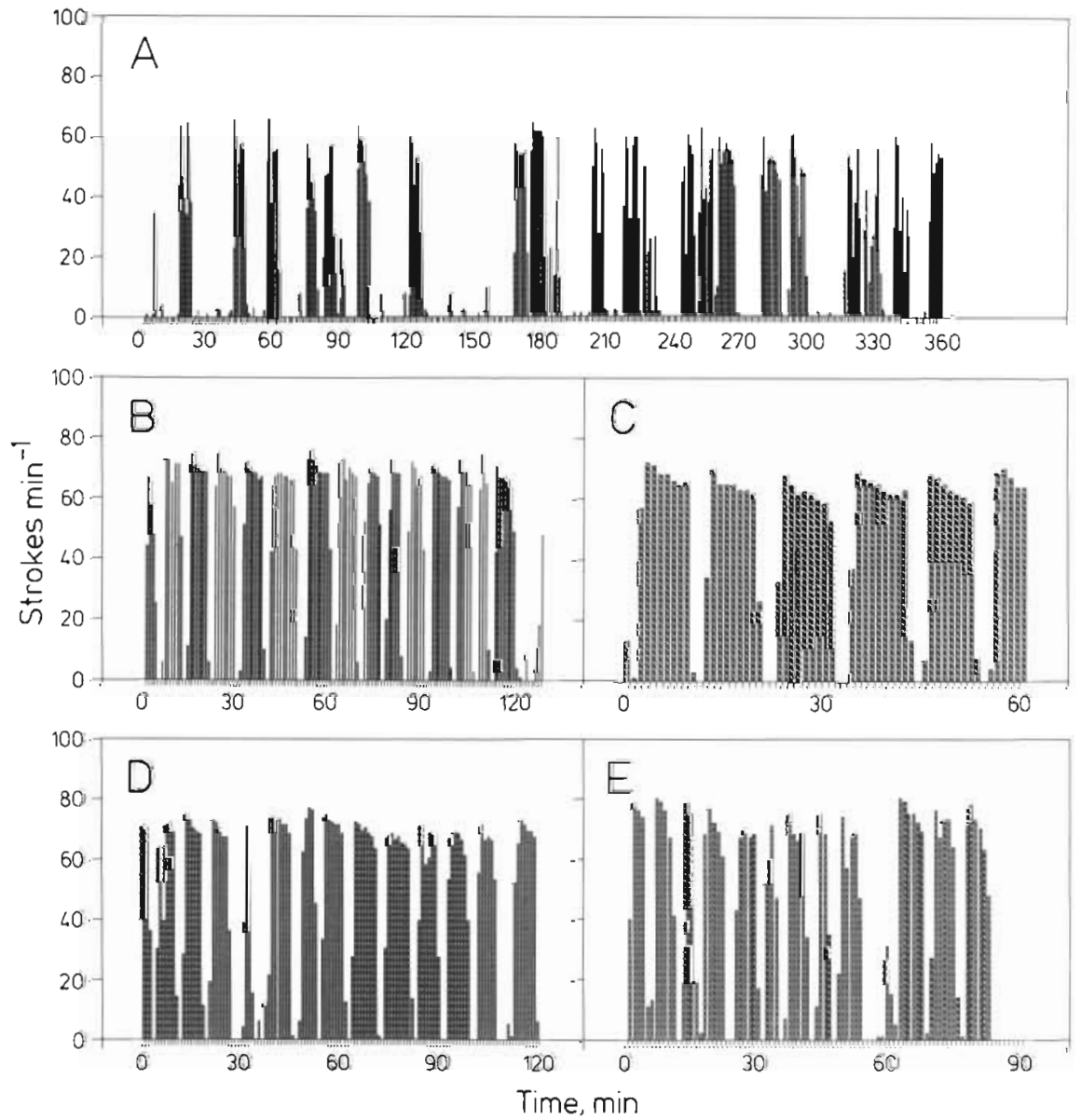


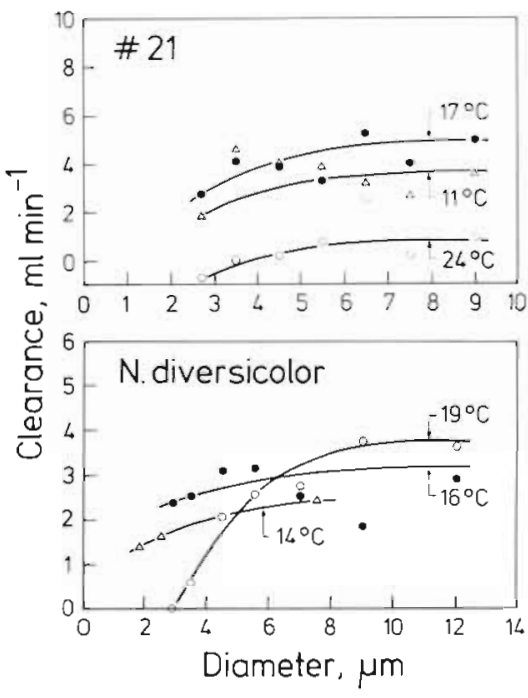

Fig. 6. Nereis diversicolor. Simultaneously measured clearance of variously sized algae in experiments with Worm \#21 and a group of 3 worms. Curves were drawn by eye

tube (Figs. $7 \& 8$ ). Observations indicate 3 posteriorly propagating waves in different phase, one of which creates an effective stroke responsible for the pumping action. The effective wave peaks make firm contact
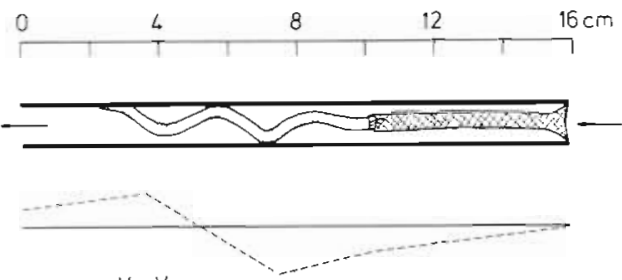

$V_{P} V_{L}$

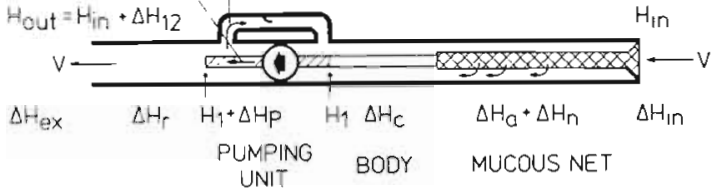

Fig. 7. Nereis diversicolor. Schematic model of a suspensionfeeding worm in its tube, showing losses and frictional pressure drop at the inlet, $\Delta H_{\mathrm{ir}}$; across the mucous net, $\Delta H_{n i}$ in the annular space between net and tube, $\Delta H_{a}$ in flow past body, $\Delta H_{c i}$ in a length of tube, $\Delta H_{r}$ and at the exit, $\Delta H_{\text {ex }}$. The positive displacement pumping unit, delivering flow $V_{\mathrm{P}}$ at pressure rise $\Delta H_{\mathrm{P}}$, has an internal leakage flow $V_{\mathrm{L}}$ past the sealing parapodia, yielding net volume flow $V=V_{p}-V_{L}$ against internal losses and externally imposed back pressure, $\Delta H_{12}$

with the tube wall on the dorsal and ventral sides suggesting good seals. On the lateral sides, the parapodia make contact with the sidewalls of the tube,

Table 1. Nereis diversicolor. Pumping period, stroke frequency, net-spinning time, net-eating time, and length of net bag for 5 worms at different algal (Rhodomonas sp.) concentrations. Means $\pm \mathrm{SD}$; number of observations are shown in parentheses; temperature $=17^{\circ} \mathrm{C}$

\begin{tabular}{|c|c|c|c|c|c|c|c|}
\hline Worm & $\begin{array}{c}\text { Body dry } \\
\text { weight } \\
\text { (mg) }\end{array}$ & $\begin{array}{c}\text { Algal conc. } \\
\left(\times 10^{3}{\left.\text { cells } \mathrm{m}^{-1}\right)}^{-1}\right.\end{array}$ & $\begin{array}{l}\text { Pumping } \\
\text { period } \\
\text { (s) }\end{array}$ & $\begin{array}{c}\text { Stroke } \\
\text { frequency } \\
\text { (strokes } \mathrm{min}^{-1} \text { ) }\end{array}$ & $\begin{array}{c}\text { Spinning time } \\
\text { (s) }\end{array}$ & $\begin{array}{l}\text { Eating time } \\
(\mathrm{s})\end{array}$ & $\begin{array}{l}\text { Net length } \\
\quad(\mathrm{mm})\end{array}$ \\
\hline$\# 2$ & 50 & $\begin{array}{r}2.5 \\
5.0 \\
5.0 \\
10.0 \\
15.0 \\
25.0\end{array}$ & $\begin{array}{l}414 \pm 47(11) \\
372 \pm 89(13) \\
444 \pm 94(19) \\
438 \pm 100(17) \\
420 \pm 80(14) \\
342 \pm 70(16)\end{array}$ & $\begin{array}{l}58 \pm 2.3(7) \\
67 \pm 3.2(7) \\
68 \pm 2.6(16) \\
66 \pm 3.1(12) \\
69 \pm 1.3(12) \\
73 \pm 3.7(14)\end{array}$ & $\begin{array}{ll} & - \\
115 \pm 5 & (2) \\
177 \pm 18(10) \\
156 \pm 13 & (5) \\
153 \pm 3 & (4) \\
132 \pm 10 & (5)\end{array}$ & $\begin{array}{c}- \\
27 \pm 5 \quad(7) \\
29 \pm 18(10) \\
27 \pm 13 \quad(8) \\
27 \pm 3 \quad(9) \\
27 \pm 10(10)\end{array}$ & $\begin{array}{l}50 \pm 7(3) \\
65 \pm 4(12) \\
81 \pm 7(11) \\
74 \pm 7(13) \\
74 \pm 4(8) \\
71 \pm 9(15)\end{array}$ \\
\hline$\# 3$ & 29 & $\begin{array}{r}2.0 \\
2.0 \\
5.0 \\
6.5 \\
10.0 \\
20.0\end{array}$ & $\begin{array}{l}708 \pm 238(8) \\
366 \pm 95(17) \\
552 \pm 154(16) \\
468 \pm 102(11) \\
600 \pm 104(10) \\
594 \pm 75(7)\end{array}$ & $\begin{array}{l}27 \pm 1.6 \\
68 \pm 5.4(12) \\
53 \pm 5.4(13) \\
62 \pm 1.2(11) \\
49 \pm 2.1 \\
51 \pm 2.5\end{array}$ & $\begin{array}{ll}110 \pm 10 & (2) \\
119 \pm 11 & (7) \\
121 \pm 11 & (4) \\
115 \pm 11 & (5) \\
116 \pm 12 & (6) \\
130 \pm 20 & (2)\end{array}$ & $\begin{array}{lll}30 \pm & 0 & (1) \\
26 \pm 2 & (6) \\
26 \pm 3 & (6) \\
27 \pm 6 & (6) \\
26 \pm 3 & (6) \\
24 \pm 6 & (5)\end{array}$ & $\begin{array}{l}58 \pm 3 \\
66 \pm 20(15) \\
54 \pm 4(11) \\
66 \pm 10(12) \\
56 \pm 6(10) \\
62 \pm 14(10)\end{array}$ \\
\hline$\# 4$ & 58 & $\begin{array}{r}2.5 \\
15.0 \\
27.0\end{array}$ & $\begin{array}{l}318 \pm 110(7) \\
318 \pm 74(24) \\
306 \pm 83(22)\end{array}$ & $\begin{array}{l}47 \pm 4.8 \\
70 \pm 3.3 \quad(9) \\
70 \pm 1.2(13)\end{array}$ & $\begin{array}{l}101 \pm 8 \\
114 \pm 13 \\
102 \pm 15\end{array}$ & $\begin{array}{l}22 \pm 2(3) \\
20 \pm 4(6) \\
19 \pm 4(7)\end{array}$ & $\begin{array}{l}46 \pm 8(10) \\
55 \pm 10(13) \\
45 \pm 13(15)\end{array}$ \\
\hline$\because 5$ & 68 & $\begin{array}{r}3.5 \\
10.0 \\
10.0 \\
20.0 \\
25.0 \\
50.0\end{array}$ & $\begin{array}{l}414 \pm 172(22) \\
312 \pm 74(28) \\
324 \pm 88(19) \\
294 \pm 50(23) \\
258 \pm 37(13) \\
300 \pm 80(22)\end{array}$ & $\begin{array}{l}53 \pm 3.2(11) \\
61 \pm 3.7(14) \\
64 \pm 2.9(6) \\
65 \pm 2.1(10) \\
73 \pm 2.6(11) \\
72 \pm 2.8(10)\end{array}$ & $\begin{aligned} 135 \pm 7 & (3) \\
136 \pm 10 & (7) \\
78 \pm 6 & (4) \\
132 \pm 10 & (5) \\
130 \pm 0 & (5) \\
125 \pm 7 & (3)\end{aligned}$ & $\begin{array}{ll}27 \pm 4 & (3) \\
23 \pm 2 & (5) \\
20 \pm 2 & (3) \\
21 \pm 2 & (4) \\
29 \pm 2 & (3) \\
26 \pm 3 & (6)\end{array}$ & $\begin{array}{l}48 \pm 8(6) \\
66 \pm 6(10) \\
74 \pm 7(8) \\
75 \pm 4(16) \\
78 \pm 5(7) \\
77 \pm 3(9)\end{array}$ \\
\hline$\# 7$ & - & $\begin{array}{r}2.0 \\
10.0 \\
25.0 \\
45.0\end{array}$ & $\begin{array}{l}372 \pm 106(15) \\
456 \pm 85(8) \\
294 \pm 42(10) \\
276 \pm 42(8)\end{array}$ & $\begin{array}{l}69 \pm 2.8(13) \\
68 \pm 1.4 \quad(9) \\
71 \pm 0.9 \\
71 \pm 0.9\end{array}$ & $\begin{array}{c}- \\
140 \pm 0 \\
150 \pm 0 \\
-\end{array}$ & $\begin{array}{c}26 \pm 1(3) \\
- \\
30 \pm 0 \\
34 \pm 0\end{array}$ & $\begin{array}{l}79 \pm 19(14) \\
87 \pm 7(6) \\
70 \pm 0(2) \\
89 \pm 20\end{array}$ \\
\hline
\end{tabular}




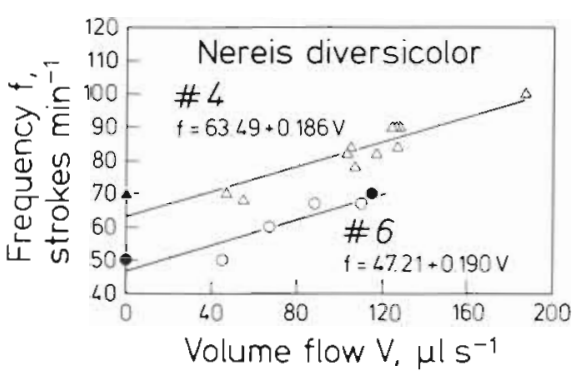

Fig. 8. Nereis diversicolor. Stroke frequency as a function of back-pressure-determined pumping rate (data from Fig. 9 in Riisgård 1991). Open symbols: experimental data; filled symbols: 'standard' values (cf. Table 2)

forming less perfect seals that may leak with increasing back pressure. A pump design such as this has features in common with mechanical positive displacement pumps, such as the gear pump and the screw pump, even though in the present case the motion is not rotating but linearly undulating. These morphologically based suggestions of a positive displacement pump that leaks more and more as back pressure is increased seem to agree with the general form of experimental back pressure characteristics (Fig. 9 in Riisgård 1991 and present Fig. 9). A non-leaking positive displacement pump would have a vertical characteristic, showing constant flow at all values of back pressure. Clearly, this is not the case for the data in Fig. 9, except at vanishing values of back pressure. As the back pressure is increased, the flow data show a progressive decrease, yielding a curve which implies internal leakage in the pump. This leakage is more pronounced at low stroke frequencies ('low gear') around 70 strokes $\mathrm{min}^{-1}$ (see Worms \#6 and \#13 in Fig. 9 of Riisgard 1991, or \#6 in present Fig. 9) than at high stroke frequencies ('high gear') around 80 to 90 strokes $\mathrm{min}^{-1}$ (see Worms \#4 and \#17 in Fig. 9 of Riisgård 1991, or \# 4 in present Fig, 9).

Based on the foregoing considerations, the pump was modelled as a positive displacement leaking unit, as shown in Fig. 7. The pumping rate is the difference between the volume flow $V_{\mathrm{P}}$ of a leak-free pump and the volume flow $V_{L}$ of leakage,

$$
V=V_{\mathrm{P}}-V_{\mathrm{L}}
$$

where

$$
V_{\mathrm{P}}=A_{\mathrm{P}} L f \text { and } V_{\mathrm{L}}=C_{\mathrm{L}} A_{\mathrm{L}} \Delta H_{\mathrm{P}} / v
$$

Here, $A_{P}, L$ and $f$ denote area, stroke length and frequency of the pumping action, respectively. $A_{\mathrm{L}}$ denotes the slit area through which viscous leakage flow is driven by excess pressure $\left(\Delta H_{\mathrm{P}}\right), v$ denotes the kinematic viscosity, and $C_{\mathrm{L}}$ is a constant.

The available area for leakage flow, $A_{\mathrm{L}}$, may not be constant but increases with increasing excess pressure.

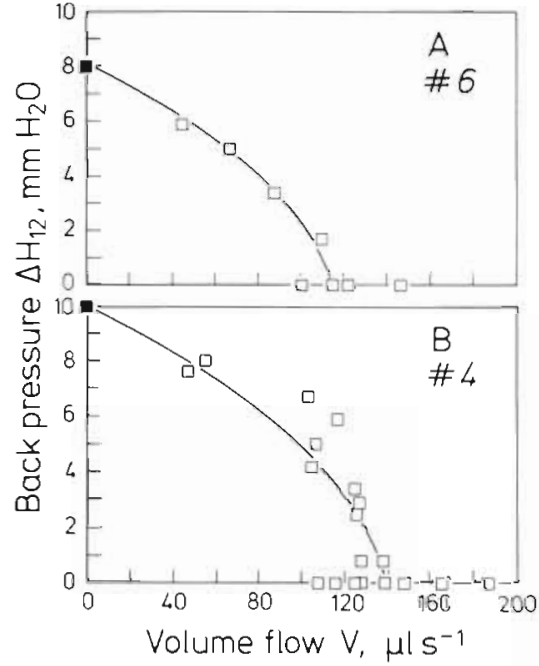

Fig. 9. Nereis diversicolor (A) Predicted back pressure values of 'standard', low gear Worm \#6 based on Eq. (5). Ex Experimental data (from Fig. 9 in Riisgård 1991); - 'standard' value (see Table 2). (B) Predicted back-pressure values of 'standard', high gear Worm \#4. Symbols as in (A). Data on volume flow at zero back pressure were obtained on different days (i.e. different stroke frequencies, which explains the scatter in data), whereas the measurements at various imposed back pressures were made in one series on the same day

This is true for a spring-loaded valve under static conditions, which for example may represent a crude model of the seals provided by the parapodia. Furthermore, under dynamic conditions the opening of the valve may be retarded at increasing stroke frequency. The resulting reduction in amplitude of valve opening may be modelled as a mechanical system for which the amplitude depends on the ratio $f / f_{\mathrm{r}}$, where $f_{\mathrm{r}}$ denotes a characteristic frequency. For lack of further information we assume a simple second-order system. Such a system is the simplest one that models the motion of a mass subject to some restoring elastic (spring) force. Therefore, for a simple model, if valve area depends linearly on excess pressure and inversely on frequency, as $A_{\mathrm{P}} \approx \Delta H_{\mathrm{P}} /\left[1+\left(f / f_{\mathrm{r}}\right)^{2}\right]$, and if the stroke length $L$ and area $A_{\mathrm{P}}$ of the pump are taken to be constants, then Eqs. (1) \& (2) give the following characteristic for the pumping unit:

$$
V=V_{\mathrm{P} 0}\left(f / f_{0}\right)-C_{\mathrm{L}}\left(\Delta H_{\mathrm{P}}\right)^{2}\left(v / v_{0}\right)^{-1}\left[1+\left(f / f_{\mathrm{f}}\right)^{2}\right]^{-1},
$$

where subscript 0 refers to a reference state, e.g. the normal operating point, at volume flow $V_{\mathrm{PO}}$ and frequency $f_{0}$. The characteristic frequency $f_{\mathrm{r}}$, which models a purely mechanical feature, is taken to be a constant throughout ( $=50$ strokes $\mathrm{min}^{-1}$ ).

Next, the pressure distribution through the tube containing an organism should be considered, as shown schematically in Fig. 7. The pressure rise over the pump, $\Delta H_{P}$, must equal the sum of contributions for 
viscous losses at the inlet and in the net and tube $\Delta H_{f}$ kinetic energy at the exit, $\Delta H_{\text {exi }}$ and the imposed back pressure $\Delta H_{12}$ :

$$
\Delta H_{\mathrm{P}}=\Delta H f+\Delta H_{\mathrm{ex}}+\Delta H_{12} .
$$

Here, the sum of all viscous losses is of the form $\Delta H f \approx$ $V$ for laminar flow, while $\Delta H_{\mathrm{ex}} \approx V^{2}$. However, this kinetic term can be safely ignored compared to other terms in Eq. (4) (see Table 2), since exit velocity does not exeed $10 \mathrm{~mm} \mathrm{~s}^{-1}$, yielding only $\Delta H_{e x}=V^{2} / 2 g \approx$ $0.005 \mathrm{~mm} \mathrm{H}_{2} \mathrm{O}$, where $g$ is acceleration due to gravity.

Substituting Eq. (4) into Eq. (3), employing the foregoing reference state, we obtain the back pressure model:

$V=V_{\mathrm{PO}}\left(f / f_{0}\right)$

$-C_{\mathrm{L}}\left[\Delta H_{f_{0}}\left(V / V_{0}\right)\left(v / v_{0}\right)+\Delta H_{12}\right]^{2}\left(v / v_{0}\right)^{-1}\left[1+\left(f / f_{\mathrm{r}}\right)^{2}\right]^{-1}$.

In effect, Eq. (5) gives $V\left\{\Delta H_{12}\right\}$, or $\Delta H_{12}\{V\}$, including the effects of changing pump frequency and fluid viscosity. To use Eq. (5) we determine the total frictional pressure drop $\Delta H_{f_{0}}$ at the operating point from theoretical calculations based on known geometry and volume flow $V_{0}$. Constants $C_{\mathrm{L}}$ and $V_{\mathrm{P}}$ are determined from 2 measurements. One is at the normal operating point, where Eq. (5) gives

$$
V_{0}=V_{\mathrm{PO}}-C_{\mathrm{L}}\left(\Delta H_{i_{0}}\right)^{2}\left[1+\left(f_{0} / f_{\mathrm{r}}\right)^{2}\right]^{-1} .
$$

For the other, at zero flow, Eq. (5) reduces to

$$
0=V_{\mathrm{PO}}\left[f(0) / f_{0}\right]-C_{\mathrm{L}}\left(\Delta H_{12}^{\circ}\right)^{2}\left[1+\left(f(0) / f_{\mathrm{r}}\right)^{2}\right]^{-1},
$$

where $\Delta H_{12}^{\circ}$ and $f(0)$ are measured at (or obtained by extrapolation of data to) $V=0$.

To complete the model and extend it to include the effect of changing temperature, $t$, we first need to know the temperature dependence of kinematic viscosity, $v(\mathrm{t})=1.83-0.06 t+0.00133 t^{2}-0.0000133 t^{3}$ (Rawson \& Tupper 1968). Also, we need to know how stroke frequency depends on both temperature and resistance to the pumping action, expressed by the pumping pressure $\Delta H_{p}$. The former dependence is expected to be biological in nature. It has been studied experimentally at zero back pressure (Figs. 2 \& 3) and may be approximated by a linear relation:

$$
f=a+b t \text { (zero back pressure). }
$$

The dependence on $\Delta H_{\mathrm{p}}$, on the other hand, is expected to be both mechanical and biological, and it is not directly amenable to experimental study. However, isothermal experiments (Fig. 9 in Riisgård 1991) show decreasing frequency with increasing back pressure, hence with increasing pumping pressure. The difference between these pressures is the frictional pressure drop, which is a small fraction of either pressure, given a large back pressure. Therefore, the above-mentioned data suggest the general behavior of the relation
$f\left(\Delta H_{P}\right)$, which proved to be well approximated by the relation

$$
f=f_{0}-c\left(\Delta H_{\mathrm{P}}\right)^{2} \text { (isothermal), }
$$

where constants $f_{0}$ and $c$ are as given in Table 2 .

According to Eq. (9), the stroke frequency asymptoti-

\begin{tabular}{|c|c|c|}
\hline Parameter & $\begin{array}{l}\text { 'Low gear' } \\
\text { Worm \#6 }\end{array}$ & $\begin{array}{l}\text { 'High gear' } \\
\text { Worm \#4 }\end{array}$ \\
\hline \multicolumn{3}{|c|}{ From experiments (Riisgård 1991): } \\
\hline$V_{0}\left(\mu l s^{-1}\right)$ & 115 & 140 \\
\hline $\bar{u}\left(\mathrm{~mm} \mathrm{~s}^{-1}\right)$ & 0.221 & 0.269 \\
\hline$f_{0}\left(\right.$ strokes $\left.\min ^{-1}\right)$ & 70 & 90 \\
\hline$f(0)\left(\right.$ strokes $\left.\min ^{-1}\right)$ & 50 & 70 \\
\hline$\Delta H_{12}^{\circ}\left(\mathrm{mm} \mathrm{H}_{2} \mathrm{O}\right)$ & 8 & 10 \\
\hline \multicolumn{3}{|c|}{ Predicted frictional pressure drop at normal conditions: } \\
\hline$\Delta H_{\mathrm{a}}\left(\mathrm{mm} \mathrm{H}_{2} \mathrm{O}\right)$ & 0.278 & 0.330 \\
\hline$\Delta H_{\mathrm{n}}\left(\mathrm{mm} \mathrm{H}_{2} \mathrm{O}\right)$ & 0.336 & 0.409 \\
\hline$\Delta H_{1}\left(\mathrm{~mm} \mathrm{H}_{2} \mathrm{O}\right)$ & 0.088 & 0.108 \\
\hline$\Delta H_{\mathrm{c}}\left(\mathrm{mm} \mathrm{H}_{2} \mathrm{O}\right)$ & 0.526 & 0.640 \\
\hline$\Delta H_{f_{0}}($ total $)\left(\mathrm{mm} \mathrm{H}_{2} \mathrm{O}\right)$ & 1.228 & 1.487 \\
\hline \multicolumn{3}{|c|}{$\begin{array}{l}\text { Constants computed from Eqs (6) \& (7) (cases for } f_{\mathrm{r}}= \\
\left.50 \text { strokes } \min ^{-1} \text { and } A_{\mathrm{L}} \approx \Delta H /\left[1+\left(f / f_{\mathrm{r}}\right)^{2}\right]\right) \text { : }\end{array}$} \\
\hline$V_{\mathrm{pO}}\left(\mu \mathrm{ls} \mathrm{s}^{-1}\right)$ & 116.86 & 142.19 \\
\hline$C_{\mathrm{L}}\left(\mu \mathrm{l} \mathrm{s}-1 / \mathrm{mm} \mathrm{H}_{2} \mathrm{O}\right)$ & 2.609 & 3.274 \\
\hline \multicolumn{3}{|c|}{$\begin{array}{l}\text { Relationship between stroke frequency }\left(f_{1} \text { strokes } \mathrm{min}^{-1} \text { ) }\right. \\
\text { and temperature }\left(t^{\circ}{ }^{\circ} \mathrm{C}\right) \text {, based on Eq. }(8) \text { and Fig. } 3 \text { (Worm } \\
\# 9 ; b=3.53 \text { ): }\end{array}$} \\
\hline$f=17$ & $4+3.53 t$ & $37.05+3.53 t$ \\
\hline \multicolumn{3}{|c|}{$\begin{array}{l}\text { Relationship between stroke frequency }\left(f \text {. strokes min }{ }^{-1} \text { ) }\right. \\
\text { and pumping pressure }\left(\Delta H_{\mathrm{p}}, \mathrm{mm} \mathrm{H}_{2} \mathrm{O}\right) \text {, based on Eq. (9) } \\
\text { and Fig. 8: } \\
\qquad f=70-0.3\left(\Delta H_{\mathrm{p}}\right)^{2} \quad f=90-0.2\left(\Delta H_{\mathrm{p}}\right)^{2}\end{array}$} \\
\hline
\end{tabular}
cally approaches a maximum value, $f_{0}$, at low resistance, a limit that is probably determined biologically.

Table 2. Nereis diversicolor. Pump model parameters of 'standard' worms at $15^{\circ} \mathrm{C}$

As resistance increases, the mechanical work load on the pump increases as $f \Delta H_{\mathrm{p}}$. Assuming constant pump power would give $f \approx 1 / \Delta H_{p}$, which does not fit the data. Apparently, Nereis diversicolor - like other biological pumps - can deliver increasing power with increasing pumping pressure until some maximum value is reached, according to Fig. 9 near zero net flow. Note that use of Eq. (9) in Eq. (5) complicates calculations which require iteration. Also, it must be stressed that the combined simultaneous effects of temperature and pumping pressure on stroke frequency have not been resolved.

\section{Parameters of 'standard' Nereis diversicolor}

Earlier data (Riisgård 1991) were examined in light of the proposed pump model and 2 'standard' incividuals 
that seem to be representative of Nereis diversicolor were examined. One was denoted the 'low gear' individual (Worm \#6; Fig. 9 in Riisgård 1991) with frequency decreasing from a maximum of 70 to about 50 strokes $\min ^{-1}$ at increasing back pressure. The other was a 'high gear' individual (Worm \#4; Fig. 9 in Riisgărd 1991), with frequency decreasing from a maximum of 90 to about 70 strokes $\mathrm{min}^{-1}$

Geometry, net bag, and tube were the same for both individuals, while volume flow $V_{0}$ under standard conditions $\left(15^{\circ} \mathrm{C}\right)$ was 115 and $140 \mu \mathrm{ls} \mathrm{s}^{-1}$, respectively, as shown in Table 2. First, the total frictional pressure drop was estimated and then characteristic parameters from experiments were identified.

Following Silvester (1983), using the modified Tamada-Fujikawa equation, the pressure drop over a uniform mucous net of rectangular mesh is expressed as

$$
\Delta H=8 \pi v \bar{u} / g h_{e} \Lambda_{e}=a \bar{u}
$$

which defines the constant $a, \bar{u}$ being the mean velocity upstream of the net; $h_{\mathrm{e}}=h_{1} h_{2} /\left(h_{1}+h_{2}\right) ; h_{1}=$ width of mesh; $h_{2}=$ length of mesh; $\Lambda_{\mathrm{e}}=1-2 \ln \tau+\tau^{2} / 6 ; \tau=$ $\pi d / h_{0} ; h_{0}=h_{1} h_{2} / \sqrt{\left(h_{1}+h_{2}\right)} ; d=$ diameter of a cylindrical fibre.

Suppose the net of total area $A=\sum_{1}^{n} A_{j}$ is composed of regions $A_{j}, j=1,2, \ldots, n$ of different mesh sizes, representing parallel flow paths of different resistances $a_{j}$ but subjected to the same pressure drop $\Delta H_{j}=a_{\mathrm{j}} \bar{u}_{\mathrm{j}}=$ $\Delta H_{\mathrm{n}}$. Then, from the continuity of total volume flow $V=A \bar{u}$ the pressure drop may be estimated from

$$
\Delta H_{\mathrm{n}}=a_{\mathrm{e}} \bar{u}=a_{\mathrm{e}} V / A ; a_{\mathrm{e}}=A / \sum_{1}^{\mathrm{n}}\left(A_{\mathrm{j}} / a_{\mathrm{j}}\right) .
$$

Clearly, Fig. 1 does not show a regular net with rectangular meshes, but rather triangular meshes for which no formula appears to be available. For an estimate, however, net mesh size may be approximated by 3 uniform, rectangular areas:

\begin{tabular}{ccccc}
\hline $\begin{array}{c}\text { Area } \\
\text { no. }\end{array}$ & $\begin{array}{c}\text { Area fraction } \\
(\%)\end{array}$ & $\begin{array}{c}h_{1} \\
(\mu \mathrm{m})\end{array}$ & $\begin{array}{c}h_{2} \\
(\mu \mathrm{m})\end{array}$ & $\begin{array}{c}\mathrm{d} \\
(\mu \mathrm{m})\end{array}$ \\
\cline { 1 - 4 } 1 & 25 & 1.2 & 1.4 & 0.030 \\
2 & 50 & 0.6 & 1.0 & 0.025 \\
3 & 25 & 0.28 & 0.42 & 0.010 \\
\hline
\end{tabular}

At $15^{\circ} \mathrm{C}\left(v_{0}=1.184 \times 10^{-6} \mathrm{~m}^{2} \mathrm{~s}^{-1}\right)$, use of Eqs. (10) \& (11) gives $a_{e}=1.518 \mathrm{~mm} \mathrm{H}_{2} \mathrm{O} \times\left(\mathrm{mm} \mathrm{s}^{-1}\right)^{-1}$, hence $\Delta H_{\mathrm{n}}=$ 0.336 and $0.409 \mathrm{~mm} \mathrm{H}_{2} \mathrm{O}$ respectively for low gear and high gear individuals, as shown in Table 2.

Additional contributions to the frictional pressure drop are derived from flow in the tube, through the annular space between body and tube, and from flows parallel to the net, both inside and outside the net bag.

For the tube $(40 \mathrm{~mm}$ length $\times 4 \mathrm{~mm}$ diameter; Fig. 7 ), assuming a fully developed Poiseuille flow, the frictional pressure drop is calculated from

$$
\Delta H_{r}=8 V v L / \pi g R^{4}
$$

where $r=$ body radius and $R=$ tube radius; this equation gives 0.088 and $0.108 \mathrm{~mm} \mathrm{H}_{2} \mathrm{O}$, respectively. for the 2 cases

For the annular space, using the expression for fully developed flow between coaxial cylinders (see e.g. Yuan 1967. p. 270)

$\Delta H_{\mathrm{C}}=\left[8 \mathrm{WL} / \pi g R^{4}\right] n^{4}\left[\left(n^{4}-1\right)-\left(n^{2}-1\right)^{2} / \ln (R / r)\right]^{-1}$,

we obtain 0.526 and $0.640 \mathrm{~mm} \mathrm{H}_{2} \mathrm{O}$, respectively, assuming a length of $40 \mathrm{~mm}$ and a tube radius: body radius ratio of $n=R / \Gamma=2 / 1$

For the flow parallel to the net bag $(63 \mathrm{~mm}$ length $x$ $2.6 \mathrm{~mm}$ diameter in the $4 \mathrm{~mm}$ diameter tube), having assumed a constant mean velocity through the net, it follows that the mean velocity of axial flow inside and outside, respectively, decreases and increases linearly. One approach is to assume a no-slip condition for axial flow along the net and to assume quasi-developed flow. Because Eqs. (12) \& (13) are linear in velocity and length, the frictional pressure drop for a flow rate that varies linearly between zero and maximum is the same as for half the flow over the full length. For the low gear individual, the frictional pressure drop is estimated accordingly: from Eq. (12) for the flow inside the net bag, giving $0.390 \mathrm{~mm} \mathrm{H}_{2} \mathrm{O}(r=1.3 \mathrm{~mm}, L=63 / 2=31.5$ $\mathrm{mm}$ ), and from Eq. (13) for the external annular flow, $1.471 \mathrm{~mm} \mathrm{H}_{2} \mathrm{O}(R=2 \mathrm{~mm}, n=2 / 1.3, L=31.5 \mathrm{~mm})$. Clearly, these results appear to be unrealistic, and they contradict the assumption of constant pressure drop over all parts of the net. In reality the net bag is somewhat conical, probably making the mean axial velocity inside and outside the net nearly the same, ca 9 to $10 \mathrm{~mm} \mathrm{~s}^{-1}$. Also, in view of the high porosity of the net and the low Reynolds numbers based on fiber diameters, a slip rather than no-slip condition for axial flow would be appropriate. In this second simplified approach twice the frictional pressure drop obtained from Eq. (12) $(R=2 \mathrm{~mm}, L=63 \mathrm{~mm})$ is used, i.e. $\Delta H_{\mathrm{a}}=$ 0.278 and $0.330 \mathrm{~mm} \mathrm{H}_{2} \mathrm{O}$, respectively, for the 2 individuals.

Ignoring the frictional pressure drop at the inlet, $\Delta H_{1 \mathrm{n}}$, as being negligible, the total frictional pressure drop becomes $\Delta H_{f_{i}}=1.228$ and $1.487 \mathrm{~mm} \mathrm{H}_{2} \mathrm{O}$, respectively. These values, as well as other parameters $\left(f_{0}, f(0)\right.$ and $\Delta H_{12}^{\circ}$ ) of standard worms \#6 and \#4 obtained from Riisgård (1991: Fig. 9), and Figs. 3 \& 8 in the present work, are given in Table 2 along with the resulting constants $V_{\mathrm{Po}}$ and $C_{\mathrm{L}}$ computed from Eqs. (6) \& (7). 


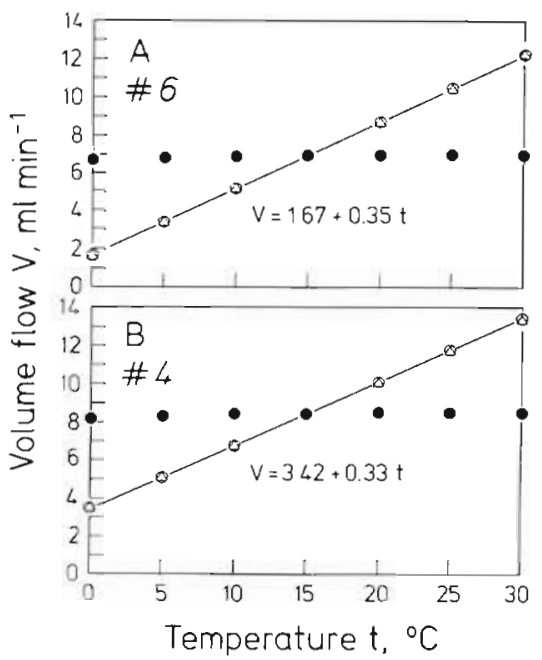

Fig. 10. Nereis diversicolor. Predicted effect of temperature on volume flow (= pumping rate) in (A) 'standard' low gear Worm \#6 and (B) 'standard' high gear Worm \#4, based on Eq. (5) for $\Delta H_{12}=0$, including: $v(t)$ and $f(t)(0) ; v(t)$ alone $(\bullet) ; f(t)$ alone $(\Delta)$. Regression lines and their equations for the intact model, including $v(t)$ and $f(t)$, are shown. The modelled relations may be compared to Worm \#10 in Fig. 3

\section{Evaluation of pump model and temperature effects}

Before studying temperature effects, the ability of the model in Eq. (5) to predict the back pressure characteristics of 'standard' Nereis diversicolor under isothermal conditions $\left(15^{\circ} \mathrm{C}\right)$ was examined. Fig. 9 shows experimental data for Worms \#6 and \#4 and model predictions from Eq. (5). The predictions are based on model parameters listed in Table 2 and a chosen value of $f_{r}=50$ strokes $\min ^{-1}$. The agreement between model and data is encouraging in view of the many unknown details in both positive displacement pump parameters and the leakage model.

Next, to examine the temperature dependence at zero back pressure, note that Worms \# 9 and \# 8 (Fig. 3) show nearly the same change in frequency per degree temperature change. Selecting \# 9 as representative,

$$
f=10.87+3.53 t
$$

where $f$ is in strokes $\mathrm{min}^{-1}$ and $t$ is in ${ }^{\circ} \mathrm{C}$; this corresponds to about 64 strokes $\min ^{-1}$ at $15^{\circ} \mathrm{C}$. Scaling this relation to 70 and 90 strokes $\mathrm{min}^{-1}$, respectively, for Worms \#6 and \#4, $f(t)$-relations at zero back pressure may be proposed.

$$
\begin{aligned}
& f=17.04+3.53 t(\text { Worm \#6) } \\
& f=37.05+3.53 t(\text { Worm \#4) }
\end{aligned}
$$

Using Eqs. (14a) \& (14b) for these individuals, the parameters $V_{\mathrm{P} 0}$ and $C_{\mathrm{L}}$ given in Table 2, and the $v(t)$ for seawater in Eq. (5), we obtain the pump model prediction of temperature dependence. For zero back pressure, the results are shown in Fig. 10. Volume flow ( $\mathrm{ml} \mathrm{min}^{-1}$ ) as a function of temperature for low gear and high gear respectively (see Table 2) is for Worm \#6

$$
V=1.67+0.35 t
$$

and for Worm \#4

$$
V=3.42+0.33 t
$$

which is reasonably close to the $V(t)$ of Worm \#10 (Fig. 3):

$$
V=1.41+0.44 t
$$

Also shown in Fig. 10 are the consequences of leaving out the effect of viscosity or stroke frequency in Eq. (5). Clearly, the temperature effect related to viscosity is negligibly small, which is not surprising since we are dealing with a positive displacement pump with limited viscosity-dependent leakage and friction. This is unlike viscous pumps, such as the ciliary gill pump of the blue mussel Mytilus edulis (Jørgensen et al. 1990) and possibly the ciliary crown-filament pump of the suspension-feeding polychaete Sabella penicillus (Riisgård \& Ivarsson 1990)

\section{Energetic costs of pumping}

The normal pump pressure or operating point $O_{\mathrm{p}}$ of the Nereis diversicolor pump may be found by adding the kinetic loss $\Delta H_{\text {ex }}$ to $\Delta H_{f_{0}}$ (see Table 2). The exit loss is given by $v^{2} / 2 g$, where $v=$ water velocity. For 'standard' $N$. diversicolor \#4 it was found that $\Delta H_{\mathrm{ex}}=$ $\left(0.140 / \pi 0.2^{2}\right) /(2 \times 980.7)=0.0057 \mathrm{~mm} \mathrm{H}_{2} \mathrm{O}$, and $O_{p}=$ $1.493 \mathrm{~mm} \mathrm{H}_{2} \mathrm{O}$. The power output $P_{\mathrm{p}}$ from the pump can be calculated as pumping pressure $\left(\Delta P=\rho g O_{p}\right.$, where $\rho=$ density of seawater) times pumping rate $V$. resulting in $2.10 \mu \mathrm{W}$ for Worm \#4 and $1.42 \mu \mathrm{W}$ for Worm \#6. With a metabolic rate $\mathrm{R}=12.6 \mu \mathrm{l} \mathrm{O}_{2} \mathrm{~h}^{-1}$ (Riisgård 1991), equivalent to $70 \mu \mathrm{W}$, the 'pump work' $P_{\mathrm{p}} / \mathrm{R}=2.10 / 70=3 \%$. This value may be compared to the 'pump work' of $4 \%$ in the exclusively suspensionfeeding polychaete Chaetopterus variopedatus (Riisgård 1989), which has a mucous trapping-net and a muscular piston pump comparable to that of Nereis diversicolor. The very similar value of pump work supports the earlier statement (Riisgărd 1991) that $N$. diversicolor fulfills conditions for subsisting exclusively as a suspension feeder. It is interesting to note that the pump and filter system of $N$. diversicolor apparently is well 'optimized' in spite of the presumably late adaptation of this polychaete to a facultative mode of life as a suspension feeder. According to both data and model, $N$. diversicolor may apparently pump against a rela- 
tively high resistance over a prolonged time and thus deliver a pump effect that is 5 to 10 times the pump effect at zero back pressure. The possible biological significance of this property of the muscular positive displacement pump in $N$. diversicolor remains obscure.

It is of considerable ecological importance to determine the extent to which Nereis diversicolor actually uses its ability to filter the water column, and thus possibly limit phytoplankton productivity, particularly in shallow brackish-water areas where this polychaete is often abundant. The system used in the present work for monitoring stroke frequency (Fig. 4) may also be applied in field investigations. Such pumping activity studies, combined with simultaneous phytoplankton biomass recordings during extended periods, are now in progress.

Acknowledgements. Thanks are due to electrical engineer Bent Bach Andersen for construction of the infrared phototransducer system, to Mrs. Edel Rasmussen for making the drawings, and to Prof. C. Barker Jergensen and Dr Jason Weeks for critically reading the manuscript.

\section{IITERATURE CITED}

Flood, P. R., Fiala-Médioni, A. (1982). Structure of the mucous feeding filter of Chaetopterus variopedatus (Polychaeta). Mar. Biol. 72: 27-33

This article was submitted to the editor
Goerke, H. (1966). Nahrungsfiltration von Nereis diversicolor O. F. Müller (Nereidae, Polychaeta). Veröff. Inst. Meeresforsch. Bremerh. 10:49-58

Harley, M. M. (1950). Occurrence of a filter-feeding mechanism in the polychaete Nereis diversicolor. Nature, Lond. 165: 734-735

Jørgensen, C. B., Larsen, P. S., Riisgård, H. U. (1990). Effects of temperature on the mussel pump. Mar. Ecol. Prog. Ser. 64: $89-97$

Leyton, L. (1975). Fluid behaviour in biological systems. Clarendon Press, Oxford

Marks, L. S. (ed.) (1941). Mechanical engineers' handbook. McGraw-Hill Book Compagny, New York

Rawson, K. J., Tupper, E. C. (1968). Basic ship theory. American Elsevier, New York

Riisgård, H. U. (1989). Properties and energy cost of the muscular piston pump in the suspension feeding polychaete Chaetopterus variopedatus. Mar. Ecol. Prog. Ser. 56: $157-168$

Riisgård, H. U. (1991). Suspension feeding in the polychaete Nereis diversicolor. Mar. Ecol. Prog. Ser. 70: 29-37

Riisgård, H. U., Ivarsson, N. M. (1990). The crown-filament pump of the suspension-feeding polychaete Sabella penicillus: filtration, effects of temperature, and energy cost. Mar. Ecol. Prog. Ser. 62: 249-257

Silvester, N. R. (1983). Some hydrodynamic aspects of filter feeding with rectangular-mesh nets. J. theor. Biol. 103: $265-286$

Vogel, S. (1981). Life in moving fluids. The physical biology of flow. Princeton University Press, New Jersey

Yuan, S. W. (1967). Foundations of fluid mechanics. PrenticeHall, Englewood Cliffs, NJ

Manuscript first received: December 10, 1991

Revised version accepted: April 15, 1992 